\title{
Study on the competitiveness of scientific research of private undergraduate university
}

\author{
MAO Chen-lei \\ School of Management, Jiangxi University of Technology, Nanchang 330098, China
}

Keywords: Private University; Competitiveness; Scientific Research; Patent; Paper

\begin{abstract}
In this paper, with the help of CNKI and China State Intellectual Property Bureau website, published papers and patents in private undergraduate universities are discussed. This paper indicates the research status and development trend of private universities in China. The results showed that scientific research of private universities tends to increase and improve. However, the development is not balanced.
\end{abstract}

\section{Introduction}

As an application type universities in China, private university takes the realization of China's higher education popularization, and cultivate qualified applied talents and skills talents needed by state, society and country industry. In recent years, private universities in China attaches great importance to the construction of connotation, significantly enhance the competitiveness of scientific research.

With the continuous advance of China's popularization of higher education, the teaching quality is increasingly becoming a hot and focus problem of government, society and universities themselves of common concern. At present, ways and means to measure and evaluate the university school quality is the main teaching quality assessment department in charge of education organizations. Because private university are very young, so the current domestic research institutions to carry out the evaluation of this type of work of universities, most of them only focus on the personnel training and the basic conditions and so on, evaluation of scientific research has not received due attention.

The author take 20 private undergraduate universities in China as an example, statistically analyze competitiveness of scientific research of various university from 2013 to now. Report as follows now:

\section{Materials and methods}

Taking into account private universities in China started late and develop slowly, this paper is intended to use the number of Chinese core paper, total paper and number of patent to represent the competitiveness of scientific research of university. The paper retrieval utilize CNKI-Chinese academic literature network publication database (website: http://www.cnki.net), From January 1, 2013 to October 28, 2014 to retrieve CNKI papers. Patent retrieval utilize the State Intellectual Property Office (http://www.pss-system.gov.cn) for authorized patent retrieval, from 1 September, 2013 to now. The above data are used first affiliation. Statistical data are processed in order to understand the competitiveness of scientific research of each private universities. According to 2014 China private colleges competitiveness rankings report published by the research center of Chinese science evaluation, I select the top twenty as the research object: Jiangxi University of Technology, 
Beijing City University, Jilin Huaqiao University Of Foreign Languages, Zhejiang Shuren University, Yantai Nanshan University, Huanghe Science and Technology College, Ningbo Dahongying University, East University of Heilongjiang, Xi'an International University, Xijing University, Sanjiang University, Taihu University of Wuxi, Jilin Animation Institute, Qingdao Binhai University, Weifang University of Science \& Technology, Xi'an Eurasia University, HIE University, Nanchang University of Technology, Yang-En University, and Hebei Institute Of Communications.

\section{Result}

Publish status of scientific paper is one of the standards to measure the level of scientific research of universities, which can indirectly reflect the current research in the universities, although the importance of the number of published papers is still controversial. As can be seen from the table, in 20 private universities, the number of total published paper in each university is uneven, the highest Weifang University of Science and Technology has published 1018 papers, the lowest Yang-En University has published only 22 papers, average of 268 is relatively low.

According to the "Chinese core list of journals", published papers of Chinese core index enthuse universities are analyzed and compared. As can be seen from the table, in 20 private universities, total published core journal paper, the average is 42, of which the highest Huanghe Science and Technology College's 173 papers, the lowest Yang-En University only 1 paper. There is a big gap among these universities.

Patent is also an important index which reflect the strength and level of scientific research of a university. As can be seen from the table, many private universities have no patent authorization, an average of 53, the highest Jiangxi University of technology has 490 active patents, and this is a relatively higher, highlighting the characteristics of application type.

Private undergraduate university, both from the students and teachers, the target of personnel training must be firmly fixed in the cultivation of applied talents. Only separating from the Research University, Teach and Research University in the training type, dislocation of private undergraduate university development, can show the private university characteristics of application type. The characteristics of private universities and the external environment determines that the innovation education and entrepreneurship education will become the future development trend of private higher education, constructing suitable innovative education system for private universities, innovating the mode of talent cultivation, and striving to cultivate qualified people with innovative consciousness and innovative ability. Let students "learn to behave, learn to do, learn to learn, learn to innovate".

Table

\begin{tabular}{|c|c|c|c|}
\hline University & $\begin{array}{c}\text { Number of total } \\
\text { published paper }\end{array}$ & $\begin{array}{c}\text { Number of } \\
\text { core journal } \\
\text { paper }\end{array}$ & $\begin{array}{c}\text { Number of } \\
\text { effective patents }\end{array}$ \\
\hline $\begin{array}{c}\text { Jiangxi University of } \\
\text { Technology }\end{array}$ & 280 & 56 & 490 \\
\hline Beijing City University & 269 & 48 & 0 \\
\hline $\begin{array}{c}\text { Jilin Huaqiao University Of } \\
\text { Foreign Languages }\end{array}$ & 143 & 13 & 162 \\
\hline Zhejiang Shuren University & 147 & 25 & \\
\hline
\end{tabular}




\begin{tabular}{|c|c|c|c|}
\hline Yantai Nanshan University & 146 & 13 & 10 \\
\hline $\begin{array}{l}\text { Huanghe Science and } \\
\text { Technology College }\end{array}$ & 759 & 173 & 212 \\
\hline $\begin{array}{c}\text { Ningbo Dahongying } \\
\text { University }\end{array}$ & 438 & 76 & 9 \\
\hline $\begin{array}{c}\text { East University of } \\
\text { Heilongjiang } \\
\end{array}$ & 257 & 21 & 66 \\
\hline Xi'an International University & 383 & 57 & 1 \\
\hline Xijing University & 240 & 114 & 25 \\
\hline Sanjiang University & 132 & 14 & 4 \\
\hline Taihu University of Wuxi & 47 & 5 & 0 \\
\hline Jilin Animation Institute & 139 & 20 & 0 \\
\hline Qingdao Binhai University & 140 & 11 & 39 \\
\hline $\begin{array}{l}\text { Weifang University of } \\
\text { Science \& Technology }\end{array}$ & 1018 & 80 & 42 \\
\hline Xi'an Eurasia University & 87 & 5 & 0 \\
\hline HIE University & 404 & 79 & 1 \\
\hline $\begin{array}{c}\text { Nanchang University of } \\
\text { Technology }\end{array}$ & 149 & 10 & 0 \\
\hline Yang-En University & 22 & 1 & 0 \\
\hline $\begin{array}{l}\text { Hebei Institute Of } \\
\text { Communications }\end{array}$ & 159 & 24 & 0 \\
\hline Average & 268 & 42 & 53 \\
\hline
\end{tabular}

\section{Discussion and Conclusion}

In this paper, with the help of Chinese CNKI and the State Intellectual Property Office website, the status of published papers and patents in private universities in China was compared and analyzed; the following conclusions can be drawn:

(1) In recent years, private universities pay more attention to the connotation construction.

(2) With the increase of number of published paper, at the same time, quality has been well protected, reflected in the number of core paper.

(3) In private universities, number of patent is uneven, some private universities get good marks in the patent application.

Because of limitation of methods, there are still some deficiencies:

(1) This study is analyzed and compared by China CNKI and China State Intellectual Property Bureau website. The omissions or errors of CNKI and website will affect the results of this study.

(2) In this paper I only analyze paper published in Chinese journals for private universities, paper published in foreign journal is not included.

This report will help to understand the situation of private university in their scientific research, enhance the consciousness and initiative in scientific research. This report can also provide the decision reference for the education department to formulate policy, at the same time can also be for students, parents and social institutions to receive important information. 
Private university is a bellwether of private higher education, and also hope of private higher education in the future, the quality and speed of development is directly related to the whole social reputation of private higher education. The development of the private university is coming into a key period from scale development to connotative development, and opportunities and challenges coexist. The private university is in an important historical stage of rapid development, the advantage of seeking difference concentration to create characteristic, break through the homogeneity of seeking development, further improve the school running quality and level, to further strengthen the scientific and technological innovation and scientific research work is very important.

Only to accurate position, to cast characteristics, to manage innovation, in the future private universities can come out on top, set up "the sign pole" for the private higher education, but also contribute to the promotion the whole social image of private higher education.

\section{Acknowledgment}

This work was supported by Jiangxi Province Office of Education of Humanities and Social Science Research [No. GL 1409].

\section{References}

[1] Wang P. and Hu JF. Comparison analysis of published paper of private universities during 2006-2008 [J]. Journal of Jiangxi Bluesky University. 2009(3): 4-6.

[2] Wang P. and Hu JF. Comparison analysis of journal of private universities during 2006-2008 [J]. Journal of Jiangxi Bluesky University. 2010(1): 18-22.

[3] Hu JF. The entrepreneurship education -- the development trend of private higher education [J]. Education and Vocation. 2007(6): 8-10. 